The Newest Sappho: P. Sapph. Obbink and P. GC inv. 105, frs. 1-4 


\section{Mnemosyne Supplements}

MONOGRAPHS ON GREEK AND

LATIN LANGUAGE AND LITERATURE

Executive Editor

G.J. Boter (VU University Amsterdam)

Editorial Board

A. Chaniotis (Oxford)

K.M. Coleman (Harvard)

I.J.F. de Jong (University of Amsterdam)

T. Reinhardt (Oxford)

VOLUME 392

The titles published in this series are listed at brill.com/mns 


\title{
The Newest Sappho: P. Sapph. Obbink and P. GC inv. 105, frs. 1-4
}

Studies in Archaic and Classical Greek Song, vol. 2

\author{
Edited by
}

Anton Bierl

André Lardinois

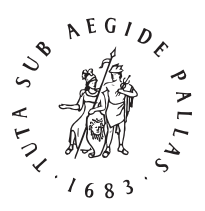

B R I L L 
B R I L L OPE N

This is an open access title distributed under the terms of the Creative Commons Attribution-Noncommercial 3.0 Unported (CC-BY-NC 3.0) License, which permits any non-commercial use, distribution, and reproduction in any medium, provided the original author(s) and source are credited.

Library of Congress Cataloging-in-Publication Data

Names: Bierl, Anton, 1960- editor. | Lardinois, A. P. M. H., editor.

Title: The newest Sappho (P. Sapph. Obbink and P. GC inv. 105, frs. 1-4) : studies in archaic and classical Greek song, vol. 2 / edited by Anton Bierl, Andre Lardinois.

Other titles: Studies in archaic and classical Greek song, vol. $2 \mid$ Mnemosyne, bibliotheca classica Batava. Supplementum ; v. 392.

Description: Leiden ; Boston : Brill, 2016.| Series: Mnemosyne. Supplements ; volume 392 | Includes bibliographical references and index.

Identifiers: LCCN 2016005748 (print) | LCCN 2016006766 (ebook) | ISBN 9789004311626 (hardback : alk. paper) | ISBN 9789004314832 (e-book)

Subjects: LCSH: Sappho-Manuscripts. | Greek poetry-Manuscripts.

Classification: LCC PA4409.N494 2016 (print) | LCC PA4409 (ebook) | DDC 884/.o1-dc23

LC record available at http://lccn.loc.gov/2016005748

Want or need Open Access? Brill Open offers you the choice to make your research freely accessible online in exchange for a publication charge. Review your various options on brill.com/brill-open.

Typeface for the Latin, Greek, and Cyrillic scripts: "Brill”. See and download: brill.com/brill-typeface.

ISSN 0169-8958

ISBN 978-90-04-31162-6 (hardback)

ISBN 978-90-04-31483-2 (e-book)

Copyright 2016 by the Editors and Authors.

This work is published by Koninklijke Brill NV. Koninklijke Brill NV incorporates the imprints Brill, Brill Hes \& De Graaf, Brill Nijhoff, Brill Rodopi and Hotei Publishing.

Koninklijke Brill NV reserves the right to protect the publication against unauthorized use and to authorize dissemination by means of offprints, legitimate photocopies, microform editions, reprints, translations, and secondary information sources, such as abstracting and indexing services including databases. Requests for commercial re-use, use of parts of the publication, and/or translations must be addressed to Koninklijke Brill NV.

This book is printed on acid-free paper and produced in a sustainable manner. 


\section{Contents}

Preface IX

List of Figures $\mathrm{X}$

Note on Abbreviations, Texts, and Translations $\quad$ XI

List of Contributors XII

Introduction 1

Anton Bierl and André Lardinois

\section{PART 1}

Sappho in the New Fragments

1 The Newest Sappho: Text, Apparatus Criticus, and Translation 13 Dirk Obbink

2 Ten Poems of Sappho: Provenance, Authenticity, and Text of the New Sappho Papyri 34

Dirk Obbink

$3 \quad$ Songs for Sailors and Lovers 55

Joel Lidov

4 Sappho, Iambist: Abusing the Brother 110

Richard P. Martin

5 The Newest Sappho and Archaic Greek-Near Eastern

Interactions 127

Kurt A. Raaflaub

6 How Did Sappho's Songs Get into the Male Sympotic

Repertoire? 148

Ewen Bowie 
PART 2

Brothers Song

7 Sappho's Brothers Song and the Fictionality of Early Greek Lyric

Poetry 167

André Lardinois

8 Hera and the Return of Charaxos $\quad 188$

Deborah Boedeker

9 Goodbye Family Gloom! The Coming of Charaxos in the Brothers Song 208

Dirk Obbink

10 Sappho and the Mythopoetics of the Domestic 225

Anastasia-Erasmia Peponi

11 Gendered Spheres and Mythic Models in Sappho's Brothers

Poem 238

Leslie Kurke

12 Larichos in the Brothers Poem: Sappho Speaks Truth to the

Wine-Pourer 266

Eva Stehle

13 The Reception of Sappho's Brothers Poem in Rome 293

Llewelyn Morgan

14 'All You Need is Love': Some Thoughts on the Structure, Texture, and Meaning of the Brothers Song as well as on Its Relation to the Kypris Song (P. Sapph. Obbink) 302

Anton Bierl

PART 3

Kypris Song

15 Sappho as Aphrodite's Singer, Poet, and Hero(ine): The

Reconstruction of the Context and Sense of the Kypris Song 339

Anton Bierl 
16 Sappho and Kypris: 'The Vertigo of Love' (P. Sapph. Obbink 21-29; P. Oxy. 1231, fr. 16) 353

Sandra Boehringer and Claude Calame

17 Loving, but not Loved: The New Kypris Song in the Context of Sappho's Poetry 368

Renate Schlesier

18 Reimagining the Fragments of Sappho through Translation 396 Diane Rayor

PART 4

Hera Song ( fr. 17)

19 Notes on the First Stanza of Fragment $17 \quad 415$

Joel Lidov

2o Sappho Fragment 17: Wishing Charaxos a Safe Trip? 424

Stefano Caciagli

21 A Poetics of Sisterly Affect in the Brothers Song and in Other Songs of Sappho 449

Gregory Nagy

Bibliography 493

Index of Passages $5^{26}$

Index of Ancient Names 539 
Anton Bierl and André Lardinois - 9789004314832 Downloaded from Brill.come4/26/2023 01:12:53PM via free access 


\section{Preface}

This is the second volume in a series within Brill's Mnemosyne Supplements which records the proceedings of the Network for the Study of Archaic and Classical Greek Song (http://greeksong.ruhosting.nl/). One volume in the series, entitled The Look of Lyric: Greek Song and the Visual, eds. Vanessa Cazzato and André Lardinois, has already been published, while two more are in preparation: on authorship and authority in Greek lyric poetry and on the reception and transmission of Greek lyric poetry from 600 BC to 400 AD. The Network was founded in 2007 as a means of facilitating interaction among scholars interested in the study of archaic and classical lyric, elegiac and iambic poetry. Most of the papers included in this volume were originally presented at the conference entitled 'Sappho in the Third Millennium', organised by Anton Bierl at the University of Basel in the Summer of 2014, or at the panel on the New Fragments of Sappho, organised by André Lardinois at the annual meeting of the Society for Classical Studies in New Orleans in January 2015. The publication of the volume was then planned jointly by Anton Bierl and André Lardinois and the papers underwent a process of peer reviewing at the hands of the editors as well as an anonymous reviewer for the Press. The contributors were also able to read each other's papers and comment on them before the manuscript went to press. We would like to express our gratitude to the anonymous reader for his fine, crystal-clear comments and his thorough revision of the manuscript. We further would like to thank Debby Boedeker, Vanessa Cazzato, Doris and Pia Degen, Hendri Dekker and Marieke Graumans, who helped us prepare the manuscript for publication, and Laurie Meijers and her team, who did an excellent job in copy-editing and composing the text. Finally, we would like to thank the Faculty of Arts of Radboud University for providing the funds which enabled this volume to be made available through Open Access. 


\section{List of Figures}

$2.1 \quad$ P. GC Inv. 105, frs. 1-4 37

2.2 P. Sapph. Obbink, containing lines $5^{-24}$ of the Brothers Song and parts of lines $1-8$ of the Kypris Song 38

2.3 Detail of P. Sapph. Obbink, showing the physical break between lines 13 and $14 \quad 39$

8.1 Map of Lesbos showing the location of ancient Messon 199

10.1 Painting of Pieter de Hooch. Interior with mother breast-feeding and child $\quad 226$ 


\section{Note on Abbreviations, Texts, and Translations}

Names of ancient authors and titles of texts are abbreviated in accordance with the list in The Oxford Classical Dictionary, fourth edition (2012) xxvi-liii. Unless otherwise specified, Greek and Latin authors are quoted from the Oxford Classical Texts, but the early Greek lyric poets - with the exception of those listed below-are cited from Campbell (1982-1993); the early Greek iambic and elegiac poets from West (1989-1992). Sappho and Alcaeus are quoted from the edition of Voigt (1971), except Sappho Fragments 58 and pre- 58 Cologne, for which the versions of Gronewald and Daniel (2007) have been used, and fragments 5 , 9, 15, 16, 16a, 17, 18, 18a, the new Brothers Song and the Kypris Song, which are cited after the new versions reproduced in this volume by Dirk Obbink (ch. 1), unless noted otherwise. The poet Pindar is quoted according to the text editions of Snell and Maehler (1987: the Epinicia) or Maehler (1989: the Fragments). Translations are by the contributors themselves, unless noted otherwise. 


\section{List of Contributors}

\section{Anton Bierl}

is Professor for Greek Literature at the University of Basel. He is director and co-editor of Homer's Iliad: The Basel Commentary and editor of the series MythosEikonPoiesis. His research interests include Homeric epic, archaic Greek poetry, drama, song and performance culture, religion, and the ancient novel. His books include Dionysos und die griechische Tragödie (1991), Die Orestie des Aischylos auf der modernen Bühne (1996), and Ritual and Performativity (2009), as well as the co-edited volumes Literatur und Religion I-II (2007), Theater des Fragments (2009), Gewalt und Opfer (2010), and Ästhetik des Opfers (2012).

\section{Deborah Boedeker}

is Professor of Classics emerita at Brown University. Her research focuses on early Greek poetry, historiography, religion, and tragedy. Recent papers include essays on the 'character' constructed by Hipponax, inconsistencies in Euripides' Helen, women in colonization narratives, the murdered heralds in Herodotus, and iambic aspects of Hermes.

\section{Sandra Boehringer}

is maitresse de conférences in Classics at the University of Strasbourg (France). She is the author of L'homosexualité féminine dans l'Antiquité grecque et romaine (Les Belles Lettres, 2007). In English she has recently published "What is named by the name 'Philaenis'? The gender, function and authority of an antonomastic figure", in Rabinowitz Nancy, Masterson Mark \& Robson John E. (ed.), Sex in Antiquity: New Essays on Gender and Sexuality in the Ancient World (Routledge, 2014) and, with Ruby Blondell, "Leaina's Revenge: The Reception of Plato's Symposium in Lucian's Fifth Dialogue of the Courtesans" (Arethusa 47, 2014).

\section{Ewen Bowie}

was Praelector in Classics at Corpus Christi College, Oxford, from 1965 to 2007, and successively University Lecturer, Reader and Professor of Classical Languages and Literature in the University of Oxford. He is now an Emeritus Fellow of Corpus Christi College. He has published articles on early Greek elegiac, iambic, and lyric poetry; on Aristophanes; on Hellenistic poetry; and on many aspects of Greek literature and culture from the first century BC to the third century AD, including Plutarch and the Greek novels. He has edited (jointly with Jaś Elsner) a collection of papers on Philostratus (CUP, 2009) and 
(jointly with Lucia Athanassaki) a collection of papers entitled Archaic and Classical Choral Song (Berlin, de Gruyter, 2011) and is currently completing a commentary on Longus, Daphnis and Chloe for CUP.

\section{Stefano Caciagli}

is Research Fellow at Bologna University. He has published a number of articles on Sappho, Alcaeus, and Alcman, as well as a book about the contextualisation of Aeolic poetry, Poeti e società. Comunicazione poetica e formazioni socialinella Lesbo del VII/VI secolo a.C. (Amsterdam, Hakkert 2011).

\section{Claude Calame}

is Director of Studies emeritus at the École des Hautes Études en Sciences Sociales in Paris (Centre AnHiMA: Anthropologie et Histoire des Mondes Antiques). In English he has published among other books Masks of Authority. Fiction and Pragmatics in Ancient Greek Poetics (Cornell University Press, 2005), Poetic and Performative Memory in Ancient Greece (CHS-Harvard University Press, 2009), Greek Mythology. Poetics, Pragmatics and Fiction (Cambridge University Press, 2009), and "Relations of Sex and Gender in Greek Melic Poetry: Helen Object and Subject of Desire" in Rabinowitz Nancy, Masterson Mark \& Robson John E. (ed.), Sex in Antiquity: New Essays on Gender and Sexuality in the Ancient World (Routledge, 2014).

\section{Leslie Kurke}

is Gladys Rehard Wood Professor of Classics and Comparative Literature at the University of California, Berkeley. She is the author of The Traffic in Praise: Pindar and the Poetics of Social Economy (Cornell, 1991), Coins, Bodies, Games, and Gold: The Politics of Meaning in Archaic Greece (Princeton, 1999), Aesopic Conversations: Popular Tradition, Cultural Dialogue, and the Invention of Greek Prose (Princeton, 2011), and numerous articles on archaic Greek poetry.

\section{André Lardinois}

is Professor of Greek Language and Literature at Radboud University, Nijmegen (the Netherlands), and the Academic Director of orkos, the national Dutch research school in Classical Studies. He has published extensively on Sappho and other Greek poetry. He is co-author of Tragic Ambiguity: Philosophy and Sophocles' Antigone (1987) and Sappho: A New Translation of the Complete Works (2014), and co-editor of Making Silence Speak: Women's Voices in Greek Literature and Society (2001), Solon of Athens: New Historical and Philological Approaches (2006) and The Look of Lyric: Greek Song and the Visual (2016). 
Joel Lidov

is Professor (Emeritus) of Classics at Queens College and the Graduate School, City University of New York. He is the author of the Oxford Bibliography of Greek Metrics, has written about the interpretation and text of Sappho and Pindar, and about the theory of Greek meter.

\section{Richard P. Martin}

is the Antony and Isabelle Raubitschek Professor in Classics at Stanford University. His primary interests are in Homeric epic, Greek comedy, mythology, and ancient religion. He is the author of The Language of Heroes (Cornell UP, 1989) and is currently at work on books concerning Homeric religion, micropolitics in Old Comedy (Sather Lectures, 2014) and Homeric poetry in comparative perspective (Martin Lectures, 2014).

\section{Llewelyn Morgan}

is a University Lecturer in Classical Languages and Literature at Oxford University, and a Fellow of Brasenose College. His work on Latin metre, especially Musa Pedestris: Metre and Meaning in Roman Poetry (Oxford, 2010), tackles inter alia the history of Latin sapphics.

\section{Gregory Nagy}

is the author of The Best of the Achaeans: Concepts of the Hero in Archaic Greek Poetry (The Johns Hopkins University Press, 1979; 2nd ed., with new Introduction, 1999). Other publications include Homer the Preclassic (University of California Press, 2010) and The Ancient Greek Hero in 24 Hours (Harvard University Press, 2013). Since 2000, he has been the Director of the Harvard Center for Hellenic Studies in Washington DC, while continuing to teach at the Harvard campus in Cambridge as the Francis Jones Professor of Classical Greek Literature and Professor of Comparative Literature.

\section{Dirk Obbink}

is Associate Professor of Papyrology and Greek Literature at the University of Oxford and tutorial fellow at Christ Church, Oxford, and co-director of The Oxyrhynchus Papyri and Ancient Lives Projects. A MacArthur Fellow, he is a papyrologist and historian of ancient Greek philosophy and religion, who developed an original method for reconstructing the carbonized scrolls of the library from Herculaneum covered by Vesuvius in 79AD. His books include Philodemus. On Piety I (1996) and Anubio. Carmen astrologicum elegiacum (2006). In 2006 he published a new poem by Archilochus on Telephus. 


\section{Anastasia-Erasmia Peponi}

is Professor of Classics at Stanford University. She works on lyric poetry (ancient and modern), Greek philosophy (especially Plato), the relationship between the verbal and the visual in ancient and early modern cultures, and theory of dance. Her recent publications include Frontiers of Pleasure: Models of Aesthetic Response in Greek Thought (Oxford University Press, 2012) and (ed.) Performance and Culture in Plato's Laws (Cambridge University Press, 2013).

\section{Kurt A. Raaflaub}

is David Herlihy University Professor and Professor of Classics and History emeritus at Brown University. His work has focused mainly on archaic and classical Greek and Roman republican social, political, and intellectual history, the social dimension of Greek warfare, and the comparative history of the ancient world. His The Discovery of Freedom in Ancient Greece was awarded the James Henry Breasted Prize of the American Historical Association. He is general editor of the series "The Ancient World, Comparative Histories."

\section{Diane J. Rayor}

is Professor of Classics at Grand Valley State University. She has published seven book translations of Greek poetry and tragedy, including Sophocles' Antigone (2011), Euripides' Medea (2013) and Sappho: A New Translation of the Complete Works (2014) with Cambridge.

\section{Renate Schlesier}

is Professor of the Study of Religion at Freie Universität Berlin. She has published extensively on tragedy as well as on Dionysos including the conference volume A Different God? Dionysos and Ancient Polytheism (De Gruyter, 2011). In recent years she has published especially on Sappho and the symposium as arguably the main poetic and pragmatic space of her compositions.

\section{Eva Stehle}

is Professor Emerita of Classics at the University of Maryland, College Park. She is the author of Performance and Gender in Ancient Greece (1997) and articles on Greek and Roman poetry, women in antiquity, and Greek religion. She is completing a book on gendered performance of Greek religious ritual. 